\title{
Performance Measurement in the Agro-industrial Supply Chain of Passion Fruit Syrup in North Sumatra Province
}

\author{
Kimberly Febrina Kodrat ${ }^{1}$, Sukaria Sinulingga ${ }^{2}$, Humala Napitupulu ${ }^{2}$ \\ ${ }^{1}$ Department of Industrial Engineering, Institut Teknologi Medan, Medan, Indonesia \\ ${ }^{2}$ Department of Industrial Engineering, Universitas Sumatera Utara, Medan,, Indonesia
}

\begin{abstract}
Passion fruit syrup is one of a typical and famous fruit as the souvenir in the form of processed products from North Sumatra Province, especially Medan City. Nowadays, the sustainability of processed products of passion fruit syrup is facing an increasingly competitive market. It is therefore necessary to measure the performance of a superior supply chain supported by the procurement of raw materials that are managed effectively and efficiently. Supply chain performance is an indicator of the success of agroindustry companies in running their business processes. Performance measurement of agroindustry supply chain is needed to control and to determine the performance position of agroindustry produced. The purpose of this study was to identify and analyze the conditions of the supply chain of passion fruit syrup agroindustry and to measure the supply chain performance of passion fruit syrup agroindustry in North Sumatra Province. The method for analyzing the conditions of the supply chain of passion fruit syrup agroindustry used a long-term relationship approach. To measure the performance of the agro-industry supply chain, the Supply Chain Operation Reference (SCOR) and AHP approach were used. The results showed that the supply chain performance of passion fruit syrup agroindustry in North Sumatra Province was $76.90 \%$ and categorized medium indicating that coordination among actors in the supply chain has not been well established

Keyword: Supply chain performance, Agroindustrial of Passion Fruit Syrup, SCOR
\end{abstract}

\section{Introduction}

Passion fruit (passifloraceae) is one of the strategic commodities. Its use as a raw material makes passion fruit syrup has nutritional value and rich in vitamin $\mathrm{C}$ which is beneficial to human body health. This plant grows in a rough area and widely found in Karo regency of North Sumatra Province which is famous as horticulture center with the clarity of climate and fertile soil, so it is potential for the development of fruit-based agro-industry. Up to this present time, passion syrup has become a distinctive commodity (trade mark) as the fruit of visitors from Medan City. Passionfruit syrup agroindustry has the potential to be developed and is one type of supply chain systems that is very interesting to study. Also, it is able to present the supply chain of agroindustry widely because it involves multi-stakeholders (farmers, collectors, processors, and retailers).

The preliminary survey shows that coordination among actors in the supply chain of passion fruit syrup is not well established due to the unfavorable flow of information and communication regarding the price and quality of the desired fruit of agroindustry. This is caused by the collecting parties never informed to the farmers regarding the standard of fruit quality desired by agro industry. Beside, the quality and quantity issues are also a problem where collectors often can not supply passion fruit to the industry in accordance with the number of orders. The collectors do not really care about it because they are not only supplying fruit to the industry but also out of Brastagi City and traditional markets with much lower quality standards and higher prices than the passion fruit juice industry. If the passion fruit is not accepted by the juice industry, the collectors sell to traditional and modern markets with a larger margin.

Chopra and Meindl (2004) states that supply chains are companies that work together to create and deliver a product into the hands of the end user. In order to fulfill the consumer's wishes, one way that can be applied is by applying supply chain management that is coordination and control of all activities in the supply chain. According to Lambert et al (1998), customer satisfaction can be realized if there is coordination and collaboration including the flow of goods, money and integrated information among those actors in the supply chain, sending them on time and with good quality.

From the above conditions, it is necessary to improve coordination among supply chain actors so that the purpose to satisfy customers can be achieved. According to Pujawan (2005), the spirit of coordination must be based on the realization that the strength of a supply chain depends on the strength of the elements in it. A healthy agroindustry does not mean anything if its suppliers can not provide quality and timely raw materials. Coordination and collaboration in the supply chain can be achieved if there is a long-term relationship. Here, the long term understanding is not regarding the emphasis on the length of the relationship that has been established, but more emphasis on the desire to establish relationships in the long term among supply chain actors (Ganesan, 1994).

Challenges and business problems in the agro-industry sector have also been found in applying supply chain management (Vorst, 2006). The emergence of problems of agro-industry supply chain management is caused by the characteristics of agricultural commodities, namely: a)perishable, b)bulky and c)seasonable and d)quality varies. Those doers throughout the supply chain are from farmers as suppliers, sales as suppliers, freight services as third party logistics, manufacturing industries as manufacturers, finished product delivery services, distributors and retailers must take into account the main characteristics of the agricultural commodity. 
With a more effective and efficient supply chain management application, it is expected to improve the coordination among supply chain actors in the passion fruit syrup agroindustry in Medan City, especially in the flow of information. If the performance of the supply chain is good, of course, the purpose of the supply chain to satisfy the desires of consumers can be realized and will have a high competitiveness that can ultimately provide benefits to each of the supply chain actors. It is therefore important to assess the performance of the supply chain to determine the current level of performance and be able to identify remediation solutions that can be made to improve the performance of the upcoming supply chain.

\section{Research Methodology}

\section{A. Location of Research}

The research was conducted in Brastagi City (as passion fruit horticulture center and passion fruit extract) and in Medan City as production and marketing center of passion fruit syrup agroindustry. The location of the study was chosen purposively with the consideration that the location is a passion agro-industry center.

\section{B. Research methods}

This research method used descriptive observational technique. Configuration of supply chain of passion fruit syrup was analyzed through APO (Asian Productivity Oganization) approach which sees the four aspects of network structure, business process, resources and supply chain management so that the objective of supply chain model of passion fruit syrup agro industry is known. Measurement of supply chain performance with SCOR (Supply Chain Operation Refference) approach was used to analyze the performance of supply chain members in each performance matrix. The actual value of the supply chain matrix was combined with the AHP weighted results obtained by organizing expert opinion. Supply chain value- added analysis is needed to see the continuity of the supply chain calculated through the Hayami value-added mathematical model in the PT X processing section which has a high supply chain performance. Supply chain of passion fruit syrup as a system is able to integrate supply chain players from suppliers to retailers (upstream-downstream).

\section{Sample Determination Method}

Determination of respondents in this study was done purposively. Respondents in this study were farmers, suppliers, agroindustry (syrup and syrup) and passion fruit syrup retailers. The number of respondents in the supply chain were 7 farmers, 5 suppliers, 3 extract agroindustry, 7 syrup agroindustry and 6 retailers.

\section{Method of collecting data}

The phases of data collection are aimed to collect information on respondent's identity and perception about post harvest process, fruit and product quality, sales data, stock of material and finished product and performance of agroindustry actors. The information was obtained from the questionnaire distribution, and then it is processed in order to be interpreted. The data obtained will be used for the analysis of current conditions, measuring the performance of the marking syrup agroindustry supply chain and calculating the added value and conducting the assessment of its suppliers.

\section{E. Instrument Validation}

The initial step before the actual pretest is done by distributing the initial questionnaires and interviews to several respondents. From the interview, some statement items or questions must be changed regarding the structure of the sentence. Furthermore, a questionnaire was conducted to determine the level of validity and reliability of the questionnaire as a means of measuring the research.

\section{F. Validity}

Questionnaires can be regarded as a good measuring tool if the questionnaire is able to demonstrate conformity with the object to be measured. Validity shows the accuracy and appropriateness of a measuring instrument in performing its measurement function. The result of the research is valid if there is similarity between the data collected with actual reality so that the data collected can represent the population under study. The validity of the questionnaires was tested using item analysis techniques, that is knowing consistency between the item scores with the overall score. Consistency can be seen in the correlation coefficient between each item with the overall score. Validity test is done by using Pearson Product Moment correlation technique with equation as follows:

Remarks

$$
\mathrm{rxy}=\frac{n \sum x y-\sum X \sum Y}{\left.\sqrt{\left[n \sum X^{2}\right.}-\left(\sum X\right)^{2}\right)\left(n \sum Y^{2}-\left(\sum Y\right)^{2}\right)}
$$

rxy = correlation between items item with total score of all items

$\mathrm{x}=$ value scores on each question or statement from all respondents

$y=$ total score of all questions or statements of all respondents

$\mathrm{n}=$ sample size

The significance test is done by t test ( $5 \%$ significance level) with the formula:

$$
\mathrm{t}=\frac{r \sqrt{n-2}}{\sqrt{1-n^{2}}}
$$




$$
d f=\mathrm{n}-2
$$

Remarks :

$\mathrm{n}=$ sample size

$\mathrm{r}=$ correlation between item items with total score of all items

The instrument question item is valid if the t-count is greater than or equal to t-table, and vice versa. In this study, the calculation of validity is fully assisted with SPSS program version 19. Validation is done to prove that the design results of this supply chain performance measurement feasible to be applied in the company. The validation technique used in this research is face validity technique, which is asking for opinions from people who have knowledge about the problem and can assess whether the theory underlying conceptual model of design of supply chain performance measurement system is correct and acceptable.

\section{G. Reliability}

Reliability measurement is aimed to show the stability and consistency of the measuring instrument (questionnaire) in measuring the concept to be measured. Reliability indicates the extent to which a measuring instrument is reliable. If a questionnaire is used twice to measure the same symptoms and the measurement results are relatively consistent then the questionnaire can be said to be reliable, in other words the reliability of the consistency of the measuring instrument (questionnaire) in measuring the concept to be measured. The high reliability of a measuring instrument is shown by a number called the reliability coefficient. At this stage, reliability testing was performed during the initial data collection of 30 respondents based on the rule of thumb popularized by Roscoe (1975) using Cronbach's Alpha technique (Sinulingga, S., 2011). The Cronbach's Alpha formula is as follows:

$$
\mathbf{r}_{\mathbf{i}}=\left(\frac{k}{k-1}\right)\left(1-\frac{\sqrt{S i}}{S_{t}}\right)
$$

Remarks:

$\mathrm{Ri}=$ reliability value

$\Sigma \mathrm{Si}=$ the number of variance score of each item

$\mathrm{St}=$ total variance and $\mathrm{k}=$ number of items

The reliability coefficient of the measuring instrument indicates the consistency level of the respondent's answer. Further, figures obtained from the calculation of Cronbach's Alpha is compared with the critical number in the correlation table $\mathrm{r}$ product moment. If the value of Cronbach's Alpha is greater than the value in the table then the statement item in the questionnaire is considered reliable. In this research, reliability calculation is fully assisted with SPSS program version 19.

\section{Data Processing Method}

\section{A. Identification of Supply Chain Agroindustry of Passionfruit Syrup}

The supply chain of passion fruit syrup agroindustry is identified by descriptive-qualitative method supported by the opinion of practitioners, field observation and literature study. The identification of the supply chain of passion fruit syrup is adapted from the method of development of supply chain according to APO (Asian Productivity Organization) modified by Van der Vorst (2006) as can be seen in Figure 1. This supply chain identification approach can describe supply chain through four main elements, that is:

1. The chain structure describes the scope of the chain and the role of chain members and the agreements that make up the chain.

2. The business process chain is a series of structured and scalable business activities to produce a certain output for consumers.

3. Network and chain management describes coordination to carry out processes in the supply chain by members.

4. Chain resources are used to produce products and deliver them to consumers. 


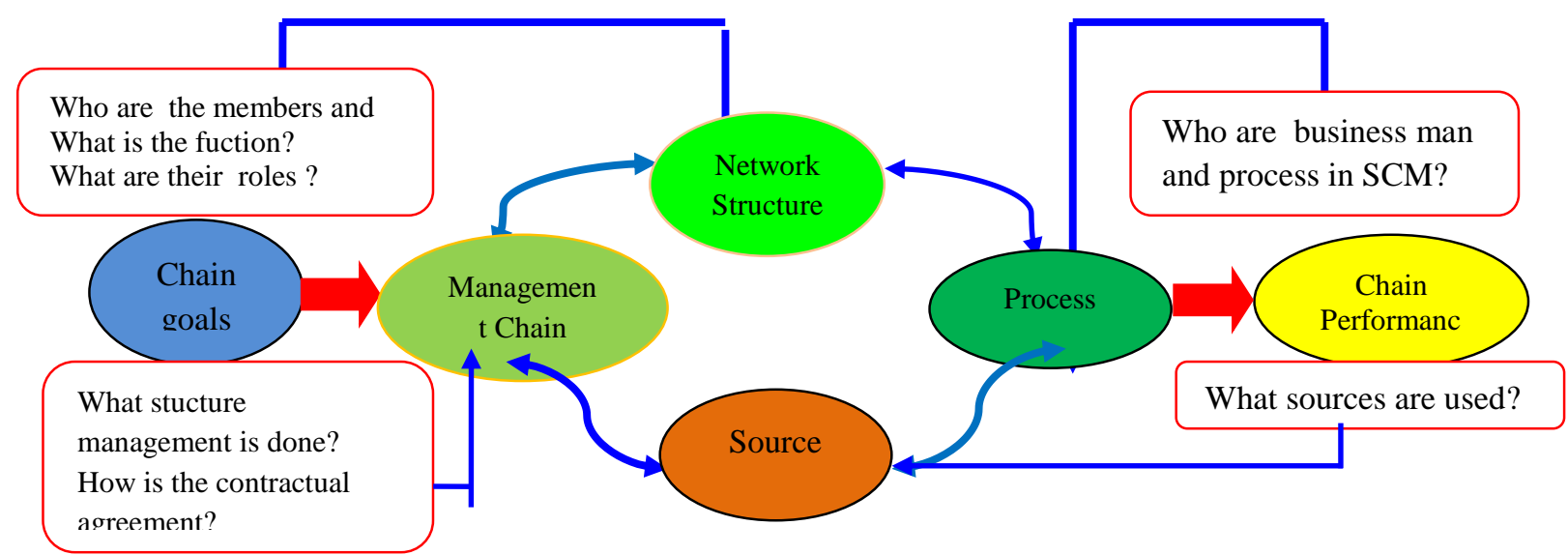

Fig 1. A frame of Supply Chain Analysis (Van der Vorst, 2006)

\section{B. Analysis of Supply Chain Agroindustry of Passion fruit Syrup}

The analysis of supply chain conditions is done with a long-term relationship approach using the "Likert" toolkit consisting of three levels or categories. Scores that exist on each question or indicator will be summed to produce a cumulative score of each respondent.

This analysis is supported by an assessment or evaluation of supply chain conditions using a long-term relationship approach (satisfaction, trust, communication, dependence and commitment) based on the opinions of selected respondents involved in supply chain of passion fruit syrup agroindustry, namely farmers, suppliers, agroindustry and passionfruit syrup agroindustry ss well as retailers. Interview results of each variable on each supply chain node is then grouped into three classes based on the cumulative score obtained. Classification of long-term relationship variables in this study can be seen in Table 1 below:

TABLE I. Classification of long -term relationship variable

\begin{tabular}{|c|c|c|c|}
\hline \multirow{2}{*}{ Variable } & \multicolumn{3}{|c|}{ Classification } \\
\hline & 1 & 2 & 3 \\
\hline Satisfaction & Not-satisfied & Satisfied & Very satisfied Satisfied \\
\hline Trust & Not Trust & Trust & Trust \\
\hline Communication & Bad & Medium & Good \\
\hline Dependency & Low & Medium & High \\
\hline Commitment & Low & Medium & High \\
\hline
\end{tabular}

\section{Performance Measurement of Passionfruit Agroindustry}

Measurement of supply chain performance follows SCOR 11 model that is standard guideline that can assist company in evaluating performance through identification and calculation of supply chain performance matrix (Kasi 2005). The SCOR model is formulated and formed into four levels of AHP decision hierarchy, namely business processes, performance parameters, performance attributes and performance matrices that can be seen in Figure 2. The business process consists of planning, procurement, cultivation, processing and delivery. Performance parameters consist of value added, risk and quality, while the description of attributes and performance matrices are shown in Table 2.

Measurement of supply chain performance is a performance measurement system that aims to help the monitoring of the running of supply chain management in order to run properly, efficiently and effectively. With the performance, measurement os achievement will be known, the problem can be known and can be searched for solution so that problem is not widespread. An integrative performance measurement system includes farmers, suppliers, agrindustries and retailers with the aim to satisfy consumers.

TABLE II. Atribute and Matrix of chain flow performance of passion fruit syrup Agroindustry

\begin{tabular}{lll}
\hline Performance atribute & Definition & Performance Matrix \\
\hline Reliability & $\begin{array}{l}\text { The performance of company in fulfilling } \\
\text { the demand of consumers in accordance with } \\
\text { what they want to add the trust of buyers. }\end{array}$ & $\begin{array}{l}\text { Order fully delivered } \\
\text { Timely delivery } \\
\text { Best goods condition }\end{array}$ \\
\hline Responsivity & $\begin{array}{l}\text { The time required by the company to fulfill } \\
\text { the demand of consumers. }\end{array}$ & $\begin{array}{l}\text { Cycle time to get raw } \\
\text { material }\end{array}$ \\
& $\begin{array}{l}\text { The ability of supply chain in giving } \\
\text { response due to the change of market in order } \\
\text { to win the market competitiveness. }\end{array}$ & $\begin{array}{l}\text { The ability of the change } \\
\text { of production capability }\end{array}$ \\
\hline
\end{tabular}




\begin{tabular}{lll}
\hline & & $\begin{array}{l}\text { Fleksibility of production } \\
\text { speed }\end{array}$ \\
\hline Cost & The required cost to run supply chain & $\begin{array}{l}\text { Processing cost } \\
\text { Maintenance cost }\end{array}$ \\
\hline
\end{tabular}

The first stage is to make the design or structure of chain performance measurement of Hierarchical structure of supply chain of passion syrup with SCOR approach in this research can be seen in Figure 2. Expert opinion is required to clarify the model and weighting priorities against the hierarchy constructed using $\alpha$ of 0.5 in accordance with the AHP technique. The use of assessment techniques in AHP is more in line with ambiguous human linguistic languages so that decisions are obtained in accordance with real situations (Dargi et al, 2014). Expert judgment results translated through the consistency index (CI) in the study was $<0.1$. This weighting result is then combined with the actual value of the supply chain matrix so that the supply chain performance is obtained

\section{Value Added Analysis}

In every business, added value is required for the investor to earn an attractive rate of return, that is exceeding the level of income on a secure investment such as bank deposits or other investments. The distribution of added value or profit throughout a supply chain must be fair and agreed upon by all members of the supply chain to maintain cooperation and sustainability ( $\mathrm{Li}$ and YuanYuan, 2005). The added value is the difference from the output value to the material cost and the input processing. The calculation of added value in the supply chain of passion fruit syrup agroindustry from upstream to downstream is done by Hayami mathematical method (Hayami et al., 1987). The Hayami value-added technique can be seen in Table 3. The added value is an increase in the value of a commodity as it adds further input or processing in a production process (Coltrain et al. 2000). Equitable distribution of value added to supply chain members is a special attraction for investors to join the business (Hidayat 2012).

\section{TABLE III. Calculation of Value-Added with Hayami Method}

\begin{tabular}{|c|c|c|}
\hline No & Variable & Value \\
\hline \multicolumn{3}{|c|}{ Output, Input and Price } \\
\hline 1 & Output (ltr) & $(1)$ \\
\hline 2 & Raw Material (Kg) & $(2)$ \\
\hline 3 & Direct Labor (HOK) & (3) \\
\hline 4 & Conversion Factor & $(4)=(1) /(2)$ \\
\hline 5 & Coefisient of Direct Labor (HOK/ltr/month) & $(5)=(3) /(2)$ \\
\hline 6 & Output Price (Rp/ltr ) & $(6)$ \\
\hline 7 & Labor Wage (Rp/HOK) & $(7)$ \\
\hline \multicolumn{3}{|c|}{ Acceptance and Profit } \\
\hline 8 & Raw material price $(\mathrm{Rp} / \mathrm{ltr})$ & $(8)$ \\
\hline 9 & Other inputs price (Rp/ltr) & $(9)$ \\
\hline 10 & Output value (Rp/ltr) & $(10)=(4) \times(6)$ \\
\hline $11 \mathrm{a}$ & Value-added (Rp/ltr) & $(11 \mathrm{a})=(10)-(8)-(9)$ \\
\hline $11 b$ & Value-added ratio $(\dot{\%})$ & $(11 b)=(11 a) /(10) \times(100) \%$ \\
\hline $12 \mathrm{a}$ & Dierct Labor Income (Rp/month) & $(12 \mathrm{a})=(5) \times(7)$ \\
\hline $12 b$ & Direct Labor market $(\%)$ & $(12 b)=(12 a) /(11 a) \times 100 \%$ \\
\hline $13 \mathrm{a}$ & Profit (Rp/month) & $(13 a)=(11 a)-(12 a)$ \\
\hline $13 b$ & Profit Level (\%) & $(13 b)=(13 a) / 10 \times 100 \%$ \\
\hline \multicolumn{3}{|c|}{ Remuneration of production factor owner } \\
\hline 14 & Margin (Rp/month) & $(14)=(10)-(8)$ \\
\hline a & Direct Labor income (\%) & $(14 a)=(12 a) /(14) \times 100$ \\
\hline $\mathrm{b}$ & Other input contribution $(\%)$ & $(14 b)=(9) /(14) \times 100 \%$ \\
\hline $\mathrm{c}$ & Company profit (\%) & $(14 c)=(13 a) /(14) \times 100 \%$ \\
\hline
\end{tabular}

\section{Results And Discussion}

Karo district with capital Kabanjahe is one of the regencies in North Sumatra Province. This district has an area of 2,127.25 $\mathrm{km} 2$ and a population of approximately 500,000 inhabitants. The district is located in the Karo highlands, Bukit Barisan North Sumatra, $77 \mathrm{~km}$ from Medan City. 
Brastagi Disitrict is as one of the districts located in Karo District, North Sumatra Province. The area of Karo Regency is divided into 17 districts. Berastagi is the second largest city in the highlands of Karo after Kabanjahe Town. In addition, it is one of the popular tourist cities in North Sumatra Province, also as a horticultural product center.

The economic activities of the people in Berastagi are centered on vegetable, fruits and tourism production, which is one of the largest vegetable and fruit producing centers in North Sumatra Province, even exported to Singapore and Malaysia.

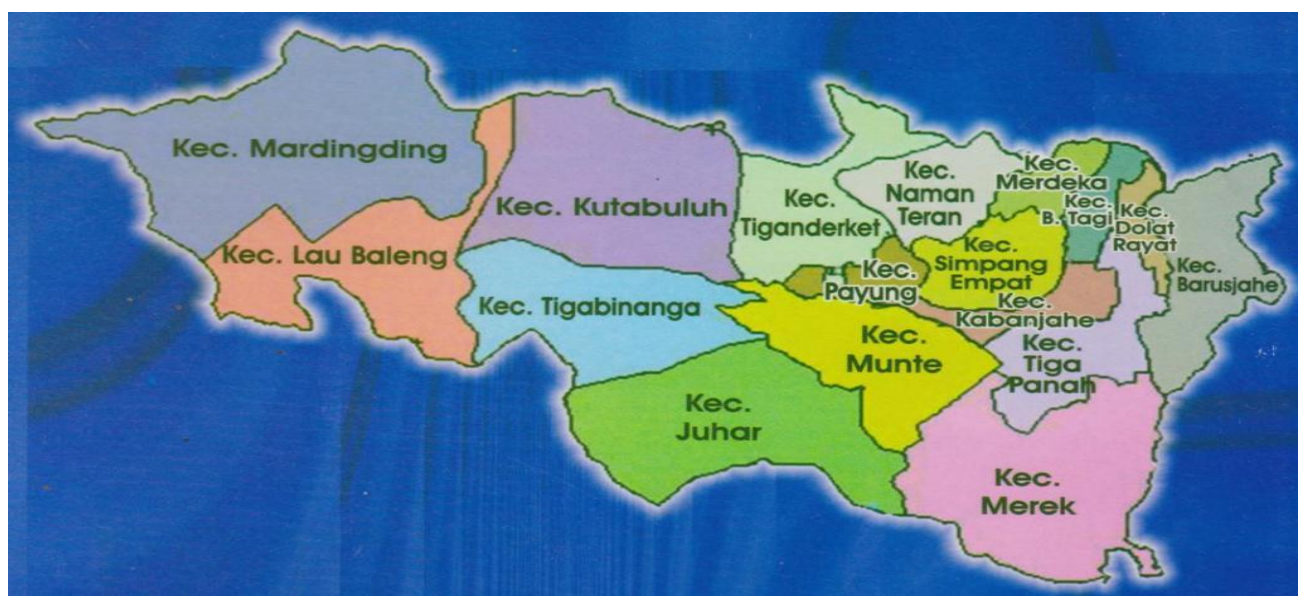

Fig 2. Map of Karo District

\section{A. Identification of Supply Chain of Passion fruit Agroindustry}

The identification of supply chain of passionfruit agro-industry is descriptively adapted from the method of supply chain development according to APO which is verified by Van der Vorst (2006) Figure 1. In Figure 5, it can be seen the flow pattern of supply chain of passion fruit syrup agroindustry where the flow of goods flows from upstream to downstream that is from farmers and suppliers that provide raw materials for production at the level of extract agroindustry and passion fruit syrup agroindustry. After the passion fruit syrup product, the flow of goods leads to the final consumer through the retailer. The flow of money is from downstream to upstream and the information flows from upstream to downstream and vice versa. This is the way of how the explanation of the flow of goods, money and information of each stakeholder agro-industrial sake of passion fruit syrup in Medan.

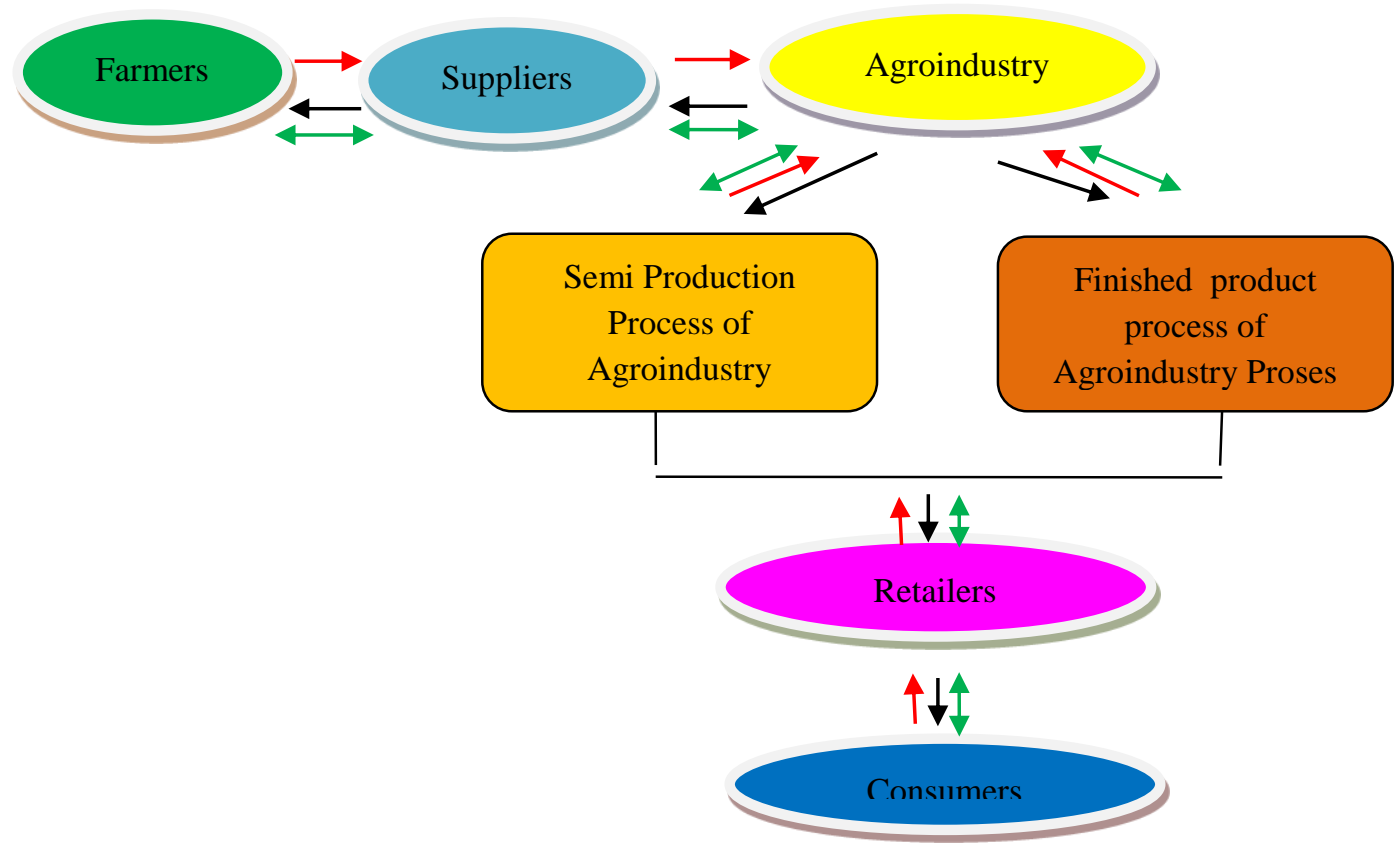

Remarks:

Fig 3. Flow Pattern on Supply Chain of Passion Fruit Syrup Agroindustry

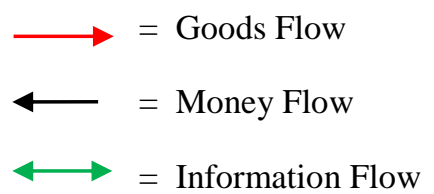




\section{B. Supply Chain Analysis of Passion Fruit Agroindustry.}

In the supply chain of passion fruit syrup agroindustry there are three kinds of flow that must be managed namely, the flow of goods, money and information. By analyzing supply chain conditions using long-term relationship variables (satisfaction, trust, communication, dependency and commitment) can be seen whether coordination is running smoothly or is still constrained. Long-term relationships can generate benefits including improved market access and reliable market information (Low, 1996). The results of supply chain analysis of passion fruit syrup agroindustry can be seen in Table 4 below:

TABLE IV. Average value of long-term relation variable

\begin{tabular}{ccccccc}
\hline \multirow{2}{*}{ No } & Supply & \multicolumn{4}{c}{ Average score Variable } \\
\cline { 3 - 7 } & Chain & Satisfaction & Trust & Communication & Depdency & Commitment \\
\hline 1 & PT - PM & 1,93 & 2,27 & 2,47 & 2,27 & 2,50 \\
2 & PM - AG & 2,40 & 2,40 & 2,20 & 2,80 & 2,60 \\
3 & AG - PCR & 2,57 & 2,85 & 2,14 & 2,28 & 2,00 \\
4 & PCR - AG & 2,00 & 2,33 & 2,50 & 2,33 & 2,67 \\
5 & AG - PM & 1,85 & 2,28 & 2,14 & 2,42 & 2,00 \\
6 & PM - PT & 2,00 & 1,80 & 2,20 & 2,20 & 2,20 \\
& Total & 12,75 & 13,93 & 13,65 & 14,30 & 13,97 \\
\hline & $\%$ & 18,58 & 20,30 & 19,89 & 20,84 & 20,36 \\
\hline
\end{tabular}

From the result of average calculation, all variables can be known regarding the highest score and percentage up to the lowest. In the following graphic, it can be seen the percentage and score of average variable.

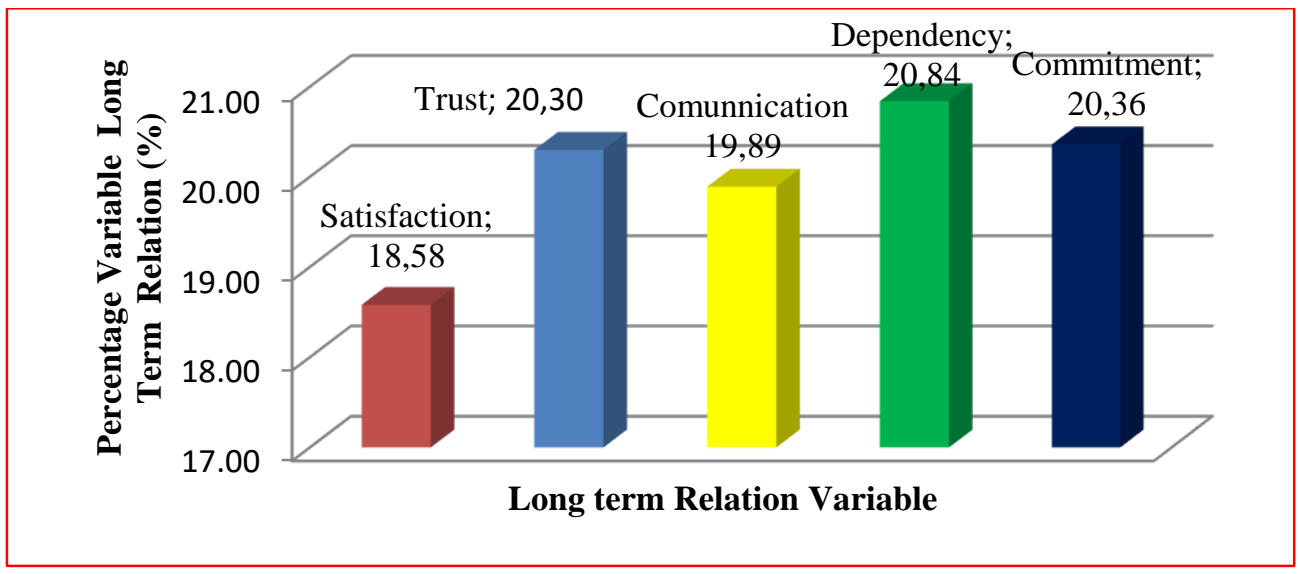

Fig 4. Average Score of Long term Relation Variable

\section{Measurement of Supply Chain Performance}

Supply chain system is one type of complex system. The characteristics of a complex system are: a). High uncertainty, b) influenced by time, c) involving multiple parties and conflicts of interest. The supply chain system of agro-industry can be identified and analyzed and measured by looking at it as a complex system, because the three conditions required as a complex system have been met.

Principles in measuring the supply chain of passion fruit syrup agroindustry are integration, coordination and collaboration in order to optimize the function of the three physical flow, information and capital. The urgency of supply chain measurement is to ensure the sustainability of passion fruit supply so that passion fruit syrup can be produced at the request of the customer and passion fruit farmer as the supplier obtains benefit in the form of competitive passion sale price.

Measurement of supply chain performance in this research using SCOR 11 model which describes supply chain in three performance attributes namely reliability, responsiveness and asset. Each of these performance attributes has several performance indicators. The results of each of these performance indicators will be known to what extent the achievement of supply chain performance of passion fruit agroindustry using internal benchmarking so that it can be given solution to improve supply chain performance in the future.

The underlying SCOR as a model for measuring the performance of the supply chain is the ability to analyze supply chains within a systematic framework, improve communication among supply chain members, and evaluate and build more efficient supply chain models (Hwang et al. 2008 and Netheginia et al. 2013). The designed performance measurement models consist of business processes, performance parameters, attributes and supply chain performance measurement matrices, formed in the hierarchy of AHP decisions can be seen in Figure 7 and the result of pergormance measurement in Table 5. 
TABLE V. Scoring result of Performance Measurement of Supply Chain of Passion Fruit Syrup Agroindustry

\begin{tabular}{lcc}
\hline Supply Chain Doers & Performance $\mathbf{( \% )}$ & Remarks \\
\hline Farmers & 75,36 & Medium \\
Collectors & 82,99 & Good \\
Semi-products Agroindustri & 81,64 & Good \\
Ãgroindustry & & \\
Dewi & 79,72 & Medium \\
Gundaling & 69,43 & Low \\
Brastagi & 69,30 & Low \\
GK & 82,13 & Good \\
Sarang Tawon & $* 82,63$ & Good \\
Pohon Pinang & 82,24 & Good \\
Piramid Unta & 82,55 & Good \\
Retailer & 77,68 & Medium \\
\hline Average & $\mathbf{7 8 , 6 9}$ & Calculation of Added Value
\end{tabular}

The calculation of added value is done only on the agronomic company which has the highest performance value among the 7 passion fruit syrup agroindustry companies (82.63) available and hereinafter referred to as PT. X can be seen in Table 6.

TABLE VI. Calculation of Value-Added with Hayami Method

\begin{tabular}{|c|c|c|}
\hline No & Variable & Value \\
\hline \multicolumn{3}{|c|}{ Output, Input and Price } \\
\hline 1 & Output (ltr) & 12.500 \\
\hline 2 & Raw Material (Kg) & 25.000 \\
\hline 3 & Direct Labor (HOK) & 3.120 \\
\hline 4 & Conversion Factor & 0,5 \\
\hline 5 & Coefisient of Direct Labor (HOK/ltr/month) & 0,1248 \\
\hline 6 & Output Price (Rp/ltr ) & 625.000 .000 \\
\hline 7 & Labor Wage (Rp/HOK) & 45.000 .000 \\
\hline \multicolumn{3}{|c|}{ Acceptance and Profit } \\
\hline 8 & Raw material price $(\mathrm{Rp} / \mathrm{ltr})$ & 125.000 .000 \\
\hline 9 & Other inputs price (Rp/ltr) & 75.000 .000 \\
\hline 10 & Output value (Rp/ltr) & 312.500 .000 \\
\hline $11 \mathrm{a}$ & Value-added (Rp/ltr) & 112.500 .000 \\
\hline $11 b$ & Value-added ratio $(\dot{\%})$ & 36 \\
\hline $12 \mathrm{a}$ & Dierct Labor Income (Rp/month) & 5.616 .000 \\
\hline $12 b$ & Direct Labor market (\%) & 5 \\
\hline $13 \mathrm{a}$ & Profit (Rp/month) & 106.884 .000 \\
\hline $13 b$ & Profit Level (\%) & 34,202 \\
\hline \multicolumn{3}{|c|}{ Remuneration of production factor owner } \\
\hline 14 & $\operatorname{Margin}(\mathrm{Rp} /$ month$)$ & 187.500 .000 \\
\hline a & Direct Labor income $(\%)$ & 3 \\
\hline $\mathrm{b}$ & Other input contribution $(\%)$ & 40 \\
\hline $\mathrm{c}$ & Company profit $(\%)$ & 57 \\
\hline
\end{tabular}

Based on the calculation of the added value of PT X, the ratio of value added 36 and the profit rate obtained is $34.2 \%$. This added value ratio is low, which can be affected by the low conversion factor due to the quality of human resources. Factor conversion of raw materials into low products such as high waste production and low productivity of the factory. Improved value added can be done by increasing the productivity of factory and labor supported by machine revitalization and improvement of human resource quality. The amount of value added in the processing part occurs because of the many additional inputs and processes on the main raw material. This is in accordance with Setiawan (2009) that the increase in added value can occur due to the introduction of input or increasing the value of prices or processes. 


\section{Supplier selection}

From the analysis of supply chain performance above, it can be concluded that there is an upstream supply chain problem that is the supply of raw material which is not in accordance with keingginan or agro-industry standard, so that the selection of potential suppliers become alternative solution for the improvement of supply chain performance on passion fruit syrup agro industry. This is in accordance with the opinion of Hou and Huang (2002) stating that the successful implementation of SCM was first determined by the supplier selection strategic decision. Supplier selection is one way that can be taken to improve supply chain competitiveness (Lee et al., 2001; Main et al., 2011).

\section{Conclusions And Recommendations}

\section{Conclusion}

a. In carrying out the supply chain activities of passion fruit syrup agroindustry, the coordination among supply chain actors is still not well established in the flow of information on the nodes of agro-industry-suppliers and suppliers-farmers.

b. The supply chain performance of passion fruit agro-industry in North Sumatera Province is categorized moderate, with average achievement of 9 performance indicators (performance matrix) consisting of: full delivery order, delivery accuracy, perfect goods condition, cycle time to get raw material, Processing cycle time, flexibility of production speed, ability of change of production speed, processing cost and maintenance cost is $76,90 \%$.

\section{Suggestion}

a. To improve the coordination of the supply chain of passion fruit agro-industry in North Sumatera Province, especially on the flow of information, each supply chain should improve the coordination, especially at the supplier-supplier node, in order to fulfill the consumer's desire to create a quality, cheap product and fulfillment time Fast and precise orders.

b. To improve the performance of the supply chain especially in order to fulfill the order of consumers to be more timely and with good quality agroindustry should use fewer suppliers with optimal performance or contract with potential suppliers.

c. This performance measurement model can be applied to other agro-industries by adjusting the performance measurement matrix.

\section{REFERENCES}

1. Aramyan, L. 2006, 'Performance Indicators in Agro-Food Production Chains', Springer, Netherland.

2. ................ 2007. Measuring Supply Chain Performance In The Agri Food Sector: a case study. Supply Chain Management: An International Journal, 2(4), 304 - 315. Springer, North Netherland.

3. Austin, J.E. 1992. Agroindustrial Project Analysis. Critical Design Factors. EDI Series in Economic Development. 2nd edition. The Johns Hopkins University Press. USA.

4. Ballou, R.H. 1999. Business Logistics Management: Planning, Organizing, and Controlling the Supply Chain. Prentice Hall Intemational, Inc. Upper Sadle River, New Jersey.

5. Bhagwat R., Sharma M.K. 2007. p.43-62 "Performance Measurement of Supply Chain Management: A balance scorecard approach 11. Journal of computer \& Industrial Engineering.

6. Beamon, B.M.1998, "Supply chain design and analysis: models and methods", International Journal of Production Economics, 55(3), 281-94.

7. ............ 1999. Measuring Supply Chain Performance. Ohio: International Journal of Operations \& Production Management, University of Cincinnati. Vol.19 No. 3, pp. 275-292.

8. Beamon B.M. and Balcik B., 2008. Performance measurement in humanitarian relief chains. International Journal of Public Sector Management, Vol. 21 No. 1, pp. 4-25.

9. Chopra, S., \& Meindl, P.,2012. Fifth edition. Supply Chain Management: Strategy, Planning, and Operation, Prentice Hall of India Private Limited, New Delhi, India.

10. Chan, F.T.S., 2003, “Performance Measurement in a Supply Chain,” Int. J. Adv. Manuf.Technol, 21 534-548.

11. Chan, FTS dan Li 2003, Feasibility of performance measurement system for Supply Chain : a process-based approach and measure, Integrated Manufacturing System 14 (3), pp.179-190.

12. Chen, I.J., \& Paulraj, A., (2004). Towards a theory of supply chain management: the constructs and measurements, Journal of Operations Management, 22: 119-150.

13. Chen, I. J., Paulraj, A. dan Lado, A. A. 2004. Strategic Purchasing, Supply Management and Firm Performance. Journal Operations Management 22, pp. 505 - 523.

14. Hadiguna, R.A., Jaafar, H.S. dan Mohamad, S. (2011). Performance Measurement for Sustainable Supply Chain in Automotive Industry: a Conceptual Framework. International Journal Value Chain Management. 5(3/4), 232-25

15. Lambert, D.M., Garcia-Dastugue, S. dan Croxton K.L. 2005. An evaluation of process-oriented supply chain management frameworks. Journal of Business Logistics 26: 25-57.

16. Lambert, D.M. 2014. Editor, Supply Chain Management: Processes, Partnerships, Performance, Fourth Edition, Ponte Vedra Beach , FL: Supply Chain Management Institute, p. 2.

17. Pujawan, I.N. 2010. Supply Chain Management. Penerbit Guna Widya, Surabaya

18. Saaty T.L., 1980. The Analytic Hierarchy Process. McGraw-Hill, New York, NY. 